\title{
Academic performance of high school students: mediating effect of study approaches
}

\author{
L. N. A. Chandana Jayawardena \& Aleš Gregar
}

\begin{abstract}
Success in higher education is viewed as an effective way of enhancing employability by the youth. This study focussed on examining the impact of high school students' study process, gender, and emotional intelligence (EI) to their academic performances. Hundred and fifteen (third year) high school students ( 52 girls, and 63 boys) were randomly selected from three high schools in Zlin, Czech Republic. Emotional intelligence of the respondents was measured through Genos El Inventory. Respondents' study process was assessed through the 'revised two-factor Study Process Questionnaire' of Biggs et al. Academic performance of the students was assessed based on their examination results. SPSS computer software was employed for the descriptive and inferential analysis of data. Study Approaches, Study Motives, and Study Strategies adopted by the respondents were assessed. Relationships were tested between the respondents' gender, age, El and academic performances. The mediating effects of study approaches to the aforementioned relationships were examined. Findings revealed a positive relationship between the gender of respondents and their academic performances. High school girls had adopted deeper study approaches and their academic performances were superior to boys. El had no significant relationship with the academic performances of the respondents. The surface study approach had a negative relationship with the academic performances of the respondents. The deep study approach did not have a relationship with the academic performances of students. The surface study ap-
\end{abstract}


proach had a mediating effect to the relationship between the gender and academic performances of high school students. Further research is recommended on varying socio-cultural contexts, and demographic segments.

Key words: Gender, Academic Performances, Study Approach, Emotional Intelligence, High School

\section{Academic Performances and Learning Styles}

Education is viewed as a form of replication of work to produce future employees (Bowles \& Gintis, 1999). However, efforts intended to promote the employability of students tend to be misguided at times. Poropot (2011) elaborated: 'if education is to fulfill its role in preparing students for work then employability should be integrated into normal educational practice, rather than added to it'. A study conducted by Whitmire (2001) on the usage of library by undergraduates found that a higher usage of academic library was shown by the students, who indicated active engagement in study activities and faculty interactions. However, the study did not reveal a strong relationship between the students' usage of library and academic performances. Poropot (2001) stated the differences between the assessment of academic performances and workplace performances could diffuse the focus on employability through education. It is pertinent to discuss 'Teaching' and the role of teachers in this respect. Schmulian and Coetzee (2001) opined on teaching style as 'Lecturers may consider the appropriateness of their style of pedagogy given the outcomes of the study and whether they are adding value in the classroom'. They have indicated those parties with a vested interest in a student's academic performance, viz: parents, sponsors, university, professional bodies etc. A lecturer provides guidance to facilitate the critical thought process, such as the improved line of students' thinking, generation of class notes etc. (Marburger, 2001).

\section{Study Process}

It has been common understanding that studying is a process, involving steps. The 'students' approaches to learning' (SAL) theory (Entwistle, Waterston, 1998 \& Biggs, 1993 ) is a meta-theory conceptualizing both teaching and learning. The ' $3 \mathrm{P}^{\prime}$ model of teaching and learning (Biggs, Kember \& Leung, 2001) consists of three levels, viz. a Presage, Process, and a Product. The presage level describes the individual differences within a given teaching context, focused on 'Student factors' and the 'Teaching Context'. Process signifies the handling of specific tasks, based on 'learning focused activities'. The product level describes the differences of teaching contexts from each other. 'The heart of the teaching/ learning system is at the process level, where the learning 
related activity produces or does not produce the desired outcomes' (Biggs, Kember \& Leung, 2001). In a study environment the roles of the teacher and the student are vital for effectiveness. Researchers suggest that the involvement (and the output) of the student is more important than the teachers' role. Herein the significance of the study approaches is focused. A recent study (Jayawardena \& Kuruppuge, 2012) found a positive relationship between the surface study approach and Academic performances of high school girls. Biggs (1999) elaborates on the study approaches: 'A generic way of describing 'what the student does' is precisely in terms of their ongoing approaches to learning'. Biggs (1999) summed up; 'A student who typically picks out likely items for assessment and rote learns them, finds that strategy won't work under portfolio assessment, so goes deep'.

\section{Emotional Intelligence}

Salovey and Mayer (1997) defined emotional intelligence (EI) as 'an individual's ability to understand emotions of one's own and others' in a manner that allows him or her to monitor them, discriminate among different emotions, and use this information effectively in shaping one's behaviour'. They defined that El involves 'the ability to perceive accurately, appraise, and express emotion, the ability to access and/or generate feelings when they facilitate thought, the ability to understand emotion and emotional knowledge, and the ability to regulate emotions to promote emotional and intellectual growth'. Empirical findings do not suggest a strong relationship between $\mathrm{El}$ and academic performances of respondents (Jayawardena \& Gregar, 2012). The ability of El to predict academic success has been found to be weaker in comparison to the cognitive ability and personality. Wagerman and Funder (2007) found that 'conscientiousness' can be successfully used to predict GPA in college seniors. Conscientiousness had accounted for $37 \%$ of the variance in GPA. Colom et al. (2007) found that sensation seeking and impulsivity were negatively correlated to Academic performance. Sanchez et al. (2001) observed that Emotional stability and Conscientiousness, have significantly contributed to an individual's academic success. Chamorro-Premuzic et al. (2001) found that El contributes to 'soft skills', which are vital for the career development of youth.

\section{Scope of the study}

The study revolves on two main research questions. Is there a relationship among Gender, El, and Academic Performances of High School Students? Is there a mediating effect of the study process approaches to the relationships between gender, and $\mathrm{EI}$ with Academic performances? The study focuses on the impact of gender, age, and 
El, and the mediating effect of study process approaches to academic performances. Specific objectives of the study were to assess and analyze the impact of gender, age, and El to academic performance of high school students, and to analyze the mediation effect of study process approaches (motives and strategies) on academic performances of high school students. By conducting the study in the Czech Republic, an attempt is made to extend the theory to culture that is more collectivist in nature than that of the West. Herein the Hofstede's cultural dimensions theory (Wikipedia contributors, August 19, 2012) adds an interesting dimension to the research findings. The conceptual framework of the study is shown by Figure 1. The study consisted of three independent variables (e.g. gender, age, and El of the respondents), two intervening/mediating variables of the study process (e.g. surface study approach, and deep study approach), and the dependent variable, i.e. academic performance of high school students. The study proposed four main research hypotheses. They are as follows:

$\mathrm{H} 1$ : There is a positive relationship between gender of high school students and their academic performances.

$\mathrm{H}$ 2: $\quad$ There is a positive relationship between El and academic performances of high school students.

H3a: The surface study approach has a mediating effect on the relationship between gender and academic performances of high school students.

$\mathrm{H} 3 \mathrm{~b}$ : The surface study approach has a mediating effect on the relationship between El and academic performances of high school students.

H4a: The deep study approach has a mediating effect on the relationship between Gender and academic performances of high school students.

H4b: The deep study approach has a mediating effect on the relationship between El and academic performances of high school students.

Figure 1: Conceptual framework of the study

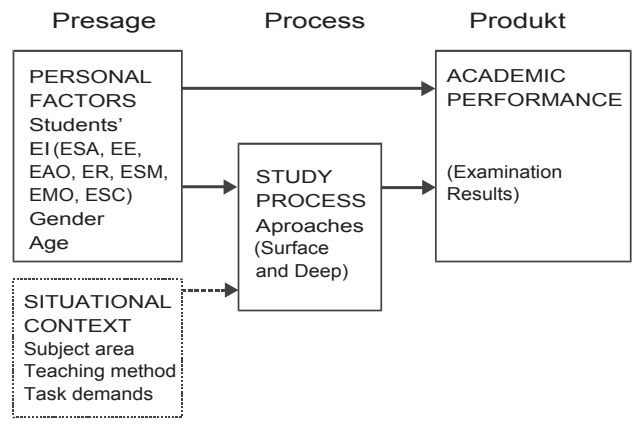

Source: A modified version of study processes using the Biggs's general model (British Journal of Educational Psychology, The British Psychological Society, 1985) 


\section{High School Education in the Czech Republic}

The education system in the Czech Republic, can be identified in four stages: i.) Preschools/Pre-primary education ( $3^{\text {nd }}$ to $6^{\text {th }}$ year), ii.) Basic schools ( $6^{\text {th }}$ to $15^{\text {th }}$ year), iii.) Secondary schools (high schools/grammar schools), secondary technical schools, secondary vocational schools and iv.) Universities (Wikipedia contributors, September 07, 2012). The Czech Republic applies free education, with the exceptions like some of preschools that are paid by parents. School education up to the age of 16 (elementary education) is mandatory. High schools are termed as 'secondary schools'. University education is provided free and students spend only on textbooks, basic equipment and food in school cafeterias. The state pays for health insurance of students up to 26 years of age (Wikipedia contributors, September 07, 2012). After completing the basic school, students are directed to three different (optional) secondary education schools. Secondary schools have the double task of preparing students to perform various occupations in the national economy, administration, culture, arts etc., and to prepare students for higher studies. The three types of schools are: a.) Secondary vocational schools (Střední odborné učiliště), providing vocational qualification programmes for 2 to 3 years for students planning to join a trade (e.g., carpentry, masonry, auto-mechanic etc.), b) Secondary technical schools (Střední odborná škola), providing secondary technical education expanding to four years in preparing students for higher education, and to hold junior positions in technical, business and other professions (accountant, technician, and kindergarten teacher), and c.) Grammar Schools (Gymnasium) prepare students to university education, and studies may last up to eight years. It could vary from four years (upper secondary) to six or eight years (lower and upper secondary) (Czesana and Simova, 2009).

\section{Methodology}

\section{Operationalization of the Study}

The study was conducted among 115 high school students (63 boys, and 52 girls) randomly selected from three high schools in Zlin, Czech Republic. Respondents were in the third academic year of senior secondary school. The Genos El Inventory was employed to assess the El level of the respondents. The Revised-SPQ-2F instrument was employed to assess their Study Process. Constructs were selected based on their merit and simplicity. The respondents' academic performance was measured by means of their performances at June 2011 and January 2012 examinations. The questionnaires were translated into the Czech language, and modified after pre-testing to enhance 
clarity. The students were briefed of the purpose of the research, and their anonymity and confidentiality of responses was assured. SPSS software was used for the descriptive and inferential data analysis. The Regression and Correlation analyses were conducted to test major relationships.

\section{Research Instruments}

The revised two-factor Study Process Questionnaire (Biggs, Kember, and Leung, 2001) and the Genos El Inventory (Gignac, 2010) were used for the study. The Study Process Questionnaire (Wagerman and Funder, 2007) focused on three dimensions of learning: viz; Surface, Deep, and Achieving. Each 'study approach' has a specific'motive' and an underlying 'strategy'. It focused on the three dimensions of learning: viz; Surface, Deep, and Achieving (refer Table 1). The revised two-factor SPQ (Revised-SPQ-2F) is an established measure focused on 'surface', and 'deep' approaches (Biggs, Kember, and Leung, 2001). The two main factors (e.g. deep and surface) distinguished the approach, motive, and strategy subcomponents. The questionnaire included 20 statements related to study activities and feelings. The items are scored on a five-point Likert scale, with responses varying from $1=$ seldom to $5=$ always.

Table 1: The Study Process Questionnaire: Dimensions, motives and strategies

\begin{tabular}{|l|l|l|l|}
\hline Parameter & Surface & Deep & Achieving \\
\hline Motive & Fear of failure & Intrinsic interest & Achievement \\
\hline Strategy & Narrow target, rote learn & Maximise meaning & Effective use of space and time \\
\hline
\end{tabular}

Source: Study Process Questionnaire, Biggs et al. 2001

Table 2: Domains of El description

\begin{tabular}{|l|l|}
\hline Name of the Factor (Sub Construct) & Description \\
\hline 1. Emotional Self-Awareness (ESA) & The skill of perceiving and understanding one's own emotions. \\
\hline 2. Emotional Expression (EE) & The skill of effectively expressing one's own emotions. \\
\hline 3. Emotional Awareness of others (EA0) & The skill of perceiving and understanding others' emotions. \\
\hline 4. Emotional Reasoning (ER) & The skill of using emotional information in decision-making. \\
\hline 5. Emotional Self-Management (ESM) & The skill of managing one's own emotions. \\
\hline 6. Emotional Mgt of Others (EMO) & The skill of positively influencing the emotions of others. \\
\hline 7. Emotional Self-Control (ESC) & The skill of effectively controlling one's own strong emotions. \\
\hline
\end{tabular}

Source: Gignac, Genos Emotional Intelligence Inventory; Technical Manual (2nd ed.), pp. 11-13. 
The Genos El Inventory focuses upon the El ability dimensions, and measures them from the performance perspective. The Genos El [20] self-report inventory (comprehensive version) consists of 70 items designed to measure the frequency with which an individual displays emotionally intelligent behaviours. The Genos El Inventory items are scored on a five-point Likert scale, with responses varying from $1=$ seldom to $5=$ always.

The Age, El, and Study approach variables had interval data. The data for the variable 'Gender' were categorical (nominal) and they were coded with 0 for boys, and 1 for girls. The data satisfied the assumptions for multiple regression analysis (Field, 2009).

\section{Findings}

The respondents' age varied from 17 to 22 years. The majority was 18 to 19 years old. The Mean (M) age of boys was 18.75 years, with a standard deviation (SD) of 0.98. Mean age of girls was 18.71 years, with a SD of 0.80 .

\section{Study process of the respondents}

The respondents expressed the nature of their study process variables, namely Study Approach (SA), Study Motive (SM), and Study Strategy (SS) using the Revised-SPQ-2F instrument.

Table 3: Study Approaches of the respondents

\begin{tabular}{|l|c|c|c|c|}
\hline \multirow{2}{*}{ Parameter } & \multicolumn{2}{|c|}{ Surface Approach } & \multicolumn{2}{c|}{ Deep Approach } \\
\cline { 2 - 5 } & Boys & Girls & Boys & Girls \\
\hline Mean (M) & 29.41 & 26.60 & 22.48 & 24.73 \\
\hline Std. Dev. & 5.27 & 7.08 & 5.12 & 5.15 \\
\hline
\end{tabular}

Source: Authors (Survey data of high school students in Zlin)

As depicted in Table 3, the boys showed a higher mean value for surface SA (29.41), and a lower mean value for the deep SA (22.48), indicating a higher reliance (than girls) on the surface study approach. The respondents showed negative values for the DSA over the SSA. In considering the net value of SA, the high school girls $(-1.87)$ relatively adapted a deeper study approach over the boys (-6.93). 
Table 4: Study Motives of the respondents

\begin{tabular}{|l|c|c|c|c|}
\hline \multirow{2}{*}{ Parameter } & \multicolumn{2}{|c|}{ Surface Motive } & \multicolumn{2}{c|}{ Deep Motive } \\
\cline { 2 - 5 } & Boys & Girls & Boys & Girls \\
\hline Mean (M) & 14.22 & 13.00 & 11.25 & 12.52 \\
\hline Std. Dev. & 3.29 & 4.31 & 3.18 & 2.66 \\
\hline
\end{tabular}

Source: Authors (Survey data of high school students in Zlin)

Study motives of the respondents were subdivided as the surface study motive (SSM) and the deep study motive (DSM). These values are depicted in Table 4. The respondents showed negative values for the DSM over the SSM. The girls indicated deeper study motives with a (DSM-SSM) net value (of -0.48 ) compared to the boys $(-2.97)$.

Table 5: Study Strategies of the respondents

\begin{tabular}{|l|c|c|c|c|}
\hline \multirow{2}{*}{ Parameter } & \multicolumn{2}{|c|}{ Surface Strategy } & \multicolumn{2}{c|}{ Deep Strategy } \\
\cline { 2 - 5 } & Boys & Girls & Boys & Girls \\
\hline Mean (M) & 15.19 & 13.60 & 11.22 & 12.21 \\
\hline Std. Dev. & 2.63 & 3.64 & 2.58 & 3.18 \\
\hline
\end{tabular}

Source: Authors (Survey data of high school students in Zlin)

The study strategies employed by the respondents were measured. They were subdivided as the surface study strategy (SSS) and the deep study strategy (DSS). Values of study strategies for the boys and the girls are depicted in Table 5. The respondents showed negative values for the DSS over the SSS. This suggested a higher dependence in the surface study strategies. The girls indicated a superior net value (DSS-SSS) of $(-1.39)$ over the boys $(-3.97)$ conforming to the trend depicted in Tables 3 , and 4.

\section{Emotional Intelligence and Academic Performances of the respondents}

Emotional Intelligence of the respondents was measured using the Genos El inventory. The respondents were allocated a score based on their responses to identified events, and contexts. The El score was identified as a total score, and also in seven subconstructs. The espondents' total El score was used for the analysis with other study variables. 
Table 6: Emotional Intelligence of the respondents

\begin{tabular}{|l|c|c|c|c|}
\hline \multirow{2}{*}{ Construct } & \multicolumn{2}{|c|}{ Boys } & \multicolumn{2}{c|}{ Girls } \\
\cline { 2 - 5 } & Mean & SD & Mean & SD \\
\hline ESA & 35.92 & 4.35 & 6.92 & 3.97 \\
\hline EE & 34.89 & 4.12 & 6.71 & 4.36 \\
\hline EA0 & 33.42 & 5.00 & 3.71 & 5.17 \\
\hline ER & 32.58 & 3.97 & 3.49 & 4.11 \\
\hline ESM & 33.24 & 3.91 & 4.10 & 3.66 \\
\hline EM0 & 31.79 & 5.31 & 4.29 & 5.37 \\
\hline ESC & 31.26 & 5.92 & 3.86 & 4.56 \\
\hline Total & 233.10 & 23.25 & 243.08 & 22.46 \\
\hline
\end{tabular}

Source: Authors (Survey data of high school students in Zlin)

The respondents' El scores are shown in Tables 6. The girls showed higher El (total) scores than the boys. The El score suggests that the girls demonstrate a slightly higher level of El than the boys. The El score of its last subconstruct, viz; Emotional Self Control showed the least value. The El scores had multiple modes, indicating the dispersion of the respondents into several clusters. Cronbach's Alpha value of $87.8 \%$ indicated a higher level of internal reliability.

Table 7: Examination marks of the respondents

\begin{tabular}{|l|c|c|}
\hline Parameter & \multicolumn{2}{|c|}{ Marks obtained (as a \%) } \\
\hline Category & Boys & Girls \\
\hline Mean (M) & 57.21 & 71.20 \\
\hline Std. Dev. & 12.95 & 13.33 \\
\hline
\end{tabular}

Source: Authors (Survey data of high school students in Zlin)

Academic performances of the respondents were assessed based on their marks obtained at the examinations in June, 2011 and January, 2012. The students' marks were averaged and depicted (as a \%) in Table 7. The girls have scored superior academic performances with 71.20 marks over 57.21 marks recorded by the boys.

\section{Gender, Age, and Academic Performances}

This study had four research hypotheses. The first hypothesis examined the relationship between the 'Gender' and 'Academic Performances' of the respondents. Therein 
the experimental hypothesis $(\mathrm{H} 1)$ suggested the existence of a significant relationship between Gender of high school students and their Academic Performances. The simple linear regression was used to test the relationship among the two variables. $Y i=b o$ + biX, where $Y$ is Academic Performance, and $X$ is Gender of the respondents. Findings indicated a significant relationship (at $\mathrm{p}<0.001$ ) between 'Gender' and "Academic performance' of the respondents. Academic Performance $=57.21+13.99 *$ Gender of high school students. The research data supported the experimental hypothesis. The high school girls ( $1=$ girls and $0=$ boys $)$ contributed with superior academic performance and outperformed the boys. In other words an addition of one high school girl contributes to increase the academic performance by 13.99 marks. Pearson correlation value ( $r$ ) between 'Gender' and Academic performance was 0.47 , and $R^{2}$ indicated that 'Gender' contributed to $22.3 \%$ of the variation of Academic performance of the high school students. The F value of 32.37 confirmed the improved prediction of the relationship. The t value of 5.69 verified that the slope of the regression line significantly varies from horizontal.

Multivariate regression (hierarchical) was used to test the relationship of Gender (Xi), Age (Xii) and El (Xiii) with Academic Performance of the respondents. However, only Gender, and Age of the respondents showed significant relationships with their Academic Performance. It can be summarized that: Academic performances of high school students $=111.09+13.07 *$ Gender of respondents $-3.68 *$ Age of the respondents. Accordingly Academic Performance indicated a positive relationship with Gender (females) of the respondents, and a negative relationship with Age (increase of Age) of the respondents. Details are depicted in Tab. 8.

Table 8: Relationship between Gender, Age, El, and Academic Performance

\begin{tabular}{|l|c|c|c|c|}
\hline Model & \multicolumn{2}{|c|}{ Unstandardized Coefficients } & Standard Coefficients & Significance \\
\hline & B & Standard Error & Beta & \\
\hline Step 1 & 126.51 & 25.13 & & .000 \\
\hline Constant & 13.72 & 2.43 & 0.46 & .000 \\
\hline Gender & -3.69 & 1.34 & -0.23 & .007 \\
\hline Age & 111.09 & 28.08 & & .000 \\
\hline Step 2 & 13.07 & 2.48 & 0.44 & .000 \\
\hline Constant & -3.68 & 1.34 & -0.22 & .007 \\
\hline Gender & 0.07 & 0.05 & 0.10 & .225 \\
\hline Age & \multicolumn{5}{|l|}{} \\
\hline El &
\end{tabular}

Note: $\mathrm{R}^{2}=0.26$ for Step 1, $\mathrm{R}^{2}$ Change $=0.01$ for Step 2, Adjusted $\mathrm{R}^{2}=0.26$ Source: Authors (Survey data of high school students in Zlin) 
The $\mathrm{R}^{2}$ indicated that Gender and Age contributed to $26 \%$ of the variation of Academic Performance of the high school students. The $F$ value of 19.92 confirmed the significance of this model (Gender, and Age with Academic Performance) and the improved prediction of the outcome. The $t$ values of 5.65 (Gender) and -2.76 (Age) confirmed that the regression line is significant. The Durbin Watson statistic of 1.44 bordered close to acceptability [21].

\section{El and Academic Performances}

The second experimental hypothesis $(\mathrm{H} 2)$ suggested a significant relationship between El and Academic Performance of the high school students. However, the data did not support it, suggesting no relationship (positive or negative) between El and Academic Performance of the high school students. The research data did not reject the null hypothesis.

\section{Mediating effect of Study Approaches to Academic Performances}

Examining the mediating effect of Study Approaches the authors focused on three basic conditions with regard to the study variables. They were as follows:

a) Assess the relationship between the independent variables (i.e. Gender, El) and the dependent variable (Academic performance) of the high school students.

b) Assess the relationship between the independent variables (i.e. Gender, El) and the mediating variable, i.e. the study process approaches of the high school students.

c) Assess the relationship between the mediating variable, i.e. the study process approaches, and the dependent variable (Academic Performance) of the high school students.

There was no significant relationship (3.4) between El and Academic Performance of the students. As a result the two research hypotheses, viz; $\mathrm{H} 3 \mathrm{~b}$, and $\mathrm{H} 4 \mathrm{~b}$ (on the mediating effect of study approaches on the relationship between El and Academic Performances) were rendered redundant. There was (3.3) a positive relationship between the Gender of respondents and their Academic performance. Simple linear regression was used to test the relationship between Gender and study approaches. $Y i=b o+b i X$, where $Y$ is the Study Process Approach, and $X$ is Gender of the respondents. There were two study approaches, i.e. the Surface Approach and the Deep Approach. The surface study approach was significant (at $p<0.05)$ with Gender. The Surface Study Approach of the 
high school students $=29.41-2.82 *$ Gender of the students. This negative relationship between Gender and the Surface Study Approach indicated that (girls $=1$, boys $=0$ ) the boys were more dependent on the surface study approach. The Pearson correlation value ( $r$ ) was 0.22 , and the $\mathrm{R}^{2}$ indicated that 'Gender' contributed only to $5.0 \%$ of the variation of the Surface Study Approach of the high school students. The F value of 5.97 and the $t$ value of 2.44 signified the model. There was no relationship (positive or negative) between 'Gender' of the respondents and their 'Deep study Approach'. Accordingly, the research hypothesis $\mathrm{H} 4 \mathrm{a}$ was rendered redundant.

Simple linear regression was used to test the relationship between the Surface Study Approach $(\mathrm{X})$ and Academic Performance of the students $(\mathrm{Y})$. Academic Performances $=$ $88.90-0.90$ * Surface Study Approach of the students $(p<0.001)$. The Pearson correlation value ( $r$ ) was 0.38 , and $R^{2}$ indicated that the 'Surface Study Approach' contributed to $14.6 \%$ of the variation of Academic Performance of the high school students ( $F=19.34$, $\mathrm{t}=-4.40)$.

Table 9: Relationship between the Surface Study Approach, Gender and Academic Performances

\begin{tabular}{|l|c|c|c|c|}
\hline \multirow{2}{*}{ Model } & \multicolumn{2}{|c|}{ Unstandardized Coefficients } & Standard Coefficients & Significance \\
\cline { 2 - 5 } & B & Standard Error & Beta & \\
\hline Step 1 & & & & \\
\hline Constant & 88.90 & 5.91 & & .000 \\
\hline SSA & -0.90 & 0.21 & -0.38 & .000 \\
\hline Step 2 & & & & .000 \\
\hline Constant & 77.40 & 5.83 & & .000 \\
\hline SSA & -0.69 & 0.19 & -0.29 & .000 \\
\hline Gender & 12.05 & 2.40 & 0.41 & \\
\hline
\end{tabular}

Note: $\mathrm{R}^{2}=0.38$ for Step $1, \mathrm{R}^{2}$ Change $=0.16$ for Step 2

Source: Authors (Survey data of high school students in Zlin)

Multivariate regression (hierarchical) was used to test the relationship of the Surface Study Approach (SA) (Xi) and Gender (Xii) with Academic Performances (Y) of the respondents. The results are shown in Table 9. It can be summarized that: Academic Performance of the high school students $=77.40-0.69 *$ SSA of the respondents $+12.05 *$ Gender of the respondents. Academic Performance indicated a negative relationship with the SSA of the respondents, and a positive relationship with Gender (girls) of the respondents. Details are depicted in Tab. 9. $\mathrm{R}^{2}$ indicated that the SSA and Gender contributed to $55 \%$ of the variation of Academic Performances of the high school students. 
The $F$ value of 24.37 confirmed the significance, and the improved predictability of this model (SSA and Gender with Academic Performance). The t values of -3.60 (SSA) and 5.03 (Gender) also verified the model. The Durbin Watson statistic of 1.53 suggested the generalizability of the findings.

Figure 2: Mediation effect of the Surface Study Approach

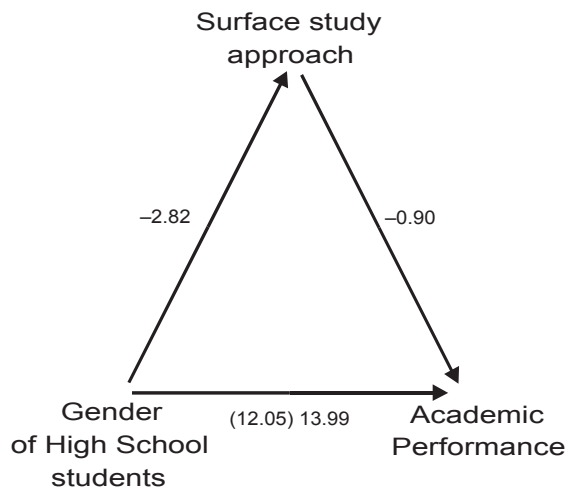

Source: Authors (Survey data of high school students in Zlin)

H3a: the experimental hypothesis suggests that the Surface Study Approach has a mediating effect on the relationship between Gender and Academic Performance of the high school students. Soble's test was used to test the mediating effect of the Surface Study Approach on the relationship between Gender and Academic Performance of the high school students. Soble's test statistic of 2.13 confirmed the significance of the effect at $p<0.05$ (two tailed). The indirect (mediation) effect on the relationship between Gender of the high school students and their Academic Performance was 2.54. This meant that an addition of one high school girl has a positive impact of 2.54 on Academic Performance, through the mediation effect.

\section{Conclusion}

The study answered the research question partly in the affirmative. The findings revealed a positive relationship between Gender (girls) and Academic performance of the Czech high school students. The girls contributed to superior academic performance. There was no significant relationship between the El level of the respondents and their academic performance. Age (increase of age) had a negative relationship 
with the Academic Performance of students. The Surface Study Approach had a positive mediating effect on the relationship between Gender and Academic Performance. It indicated an increase in the level of Academic Performance of Czech schools with a higher proportion of high school girls. Success in Academic Performance can effectively get proliferated into the future career development. And this would augur well for the career development of Czech ladies. It is premature to analyze further on the choice of 'study approaches' without details of the assessment techniques employed. Studies among larger samples of high school students will facilitate the generalization of the findings. Further research on varying socio-cultural contexts, focused on demographic segments will enrich the empirical findings.

\section{Acknowledgements}

Authors are thankful to the Internal Grant Agency of FaME TBU No. IGA/FaME/2012/038 (Emotional Intelligence, Academic Performances and Managerial Effectiveness) for financial support to this research.

\section{References}

Biggs, J. B. (1993). What Do Inventories of Students' Learning Processes Really Measure? A Theoretical Review and Clarification. British Journal of Educational Psychology, 63, pp. 1-17.

Biggs, J. B. (1999) Teaching for Quality Learning at University. Buckingham: Open University press. Biggs, J. B., Kember, D. \& Leung, D. Y. P. (2001) The Revised Two-factor Study Process Questionnaire: R-SPQ-2F. British Journal of Educational Psychology. Vol. 71, pp.133-149.

Bowles, S. \& Gintis, H. Comments on the Long Shadow of Work. Critical Sociology, 1999, Vol. 25, pp. 3-7.

Chamorro-Premuzic, T., Arteche, A., Bremner, A. J., Greven, C. \& Furnham, A. (2010) Soft Skills in Higher Education: Importance and Improvement Ratings as a Function of Individual Differences and Academic Performance. Educational Psychology, 30(2), 211-241.

Colom, R., Escorial, S., Shih, P. C. \& Privado, J. (2007) Fluid Intelligence, Memory Span, and Temperament Difficulties Predict Academic Performance of Young Adolescents'. Personality and Individual Differences. Vol. 42, pp. 1503-1514.

Czesaná, V. \& Šímová, Z. Eds. (2009). Vocational Education and Training in Europe. Country Report: Czech Republic. Fifth edition. European Centre for Development of Vocational Training, Czech Republic, pp. 38-54.

Entwistle, N. \& Waterson, S. (1988) Approaches to Studying and Levels of Processing in University Students. British Journal of Educational psychology. Vol. 58, pp. 258-265.

Field, A. (2009). Discovering Statistics Using SPSS ( $3^{\text {rd }}$ ed.). London: SAGE Publications.

Gignac, G. E. (2010). Genos Emotional Intelligence Inventory; Technical Manual. (2 ${ }^{\text {nd }}$ ed.). Sydney: Waterloo, NSW. 
Jaywardena, L. N. A. C. \& Gregar, A. (2012). Emotional Intelligence and Academic Performances of High School Students; A Case Study. Proceedings of the First WSEAS International Conference on Economics, Political and Law Science, September, 2012, pp. 119-124.

Jayawardena, L. N. A. C. \& Kuruppuge, R. H. (2012). Gender and Syllabus Based Study Approaches and Academic Performance. Journal on Efficiency and Responsibility in Education and Science. Vol. 5, No. 3, pp. 115-124 [on-line]. doi: 10.7160/ eriesj.2012.050301.

Marburger, D. R. (2001). Absenteeism and Undergraduate Exam Performance. Journal of Economic Education. Vol. 32, No. 2, pp. 99-109.

Mayer, J. D. \& Salovey, P. (1997). What Is Emotional Intelligence? In Salovey, P. \& Shuyter, D. (Eds.). Emotional Development and Emotional Intelligence: Educational Implications. New York: Basic Books, pp. 3-31.

Poropat, A. E. (2011) The Role of Citizenship Performance in Academic Achievement and Graduate Employability. Education + Training. Vol. 53, No. 6, pp. 499-514.

Sanchez, M. M., Rejano, E. I. \& Rodriguez, Y. T. (2001). Personality and Academic Productivity in the University Student. Social Behavior and Personality. Vol. 29, pp. 299-306.

Schmulian, A. \& Coetzee, S. (2011) Class Absenteeism: Reasons for Non-attendance and the Effect on Academic Performance. Accounting Research Journal. Vol. 24 No. 2, pp. 178-194.

Wagerman, S. A. \& Funder, D. C. (2007) Acquaintance Reports of Personality and Academic Achievement: A Case for Conscientiousness. Journal of Research in Personality. Vol. 41, pp. 221-229.

Whitmire, E. (2001). The Relationship Between Undergraduates' Background Characteristics and College Experiences and Their Academic Library Use. College \& Research Libraries. Vol. 62, No. 6, pp. 528-40.

WIKIPEDIA contributors, Hofstede's Cultural Dimensions Theory, Wikipedia, the Free Encyclopedia, Wikimedia Foundation, Inc. Retrieved from http://en. wikipedia.org/w/ index.php?title= Hofstede\% 27s_cultural_dimensions_theory and oldid=503581691, (2012, August, 19).

WIKIPEDIA contributors, Education in the Czech Republic, Wikipedia, the Free Encyclopedia, Wikimedia Foundation, Inc. Retrieved from http://en.wikipedia.org/wiki/Education_in_the_Czech_Republic, (2012, September, 07)

\section{Contact:}

Lead Author:

L. N. A. Chandana Jayawardena BSc (Hons), MBA

Faculty of Management and Economics

Tomáš Bata University in Zlín

Mostní 5139

76001 Zlín, Czech Republic

and Department of Agric Extension

University of Peradeniya, Sri Lanka.

E-mail: chandanacj@gmail.com

Second author:

doc. PhDr. Ing. Aleš Gregar, CSc.

Faculty of Management and Economics

Tomáš Bata University in Zlín

Mostní 5139

76001 Zlín, Czech Republic

E-mail: gregar@fame.utb.cz 